\title{
AN IMPROVED PERCUTANEOUS JETTING SYSTEM \\ FOR USE DURING MICROLARYNGEAL OPERATIONS
}

\author{
Edward Carden, Gary Becker, and Hassney Hamood
}

VENTILATION accomplished by a needle or cannula placed percutaneously into the trachea has been proposed and used for patients undergoing microlaryngeal operations. ${ }^{1,2}$ There are, however, many problems associated with its use. ${ }^{3}$ The main ones are the possible inadvertent puncture of the posterior wall of the trachea with injection of air into the mediastinum ${ }^{4}$ and inadvertent withdrawal of the cannula through the tracheal wall so that its tip lies subcutaneously. ${ }^{5}$ This withdrawal may occur when the surgeon is extending the patient's neck before inserting the laryngoscope blade, or by inadvertent traction on the tubing leading to the needle. It can cause subcutaneous emphysema and possibly pneumo-thorax or pneumomediastinum.

To obviate the first problem, a cannula should be used which is least likely to perforate the posterior wall of the trachea (i.e. a short needle). The withdrawal of air from the cannula before ventilation is mandatory. To eliminate the second problem a much longer plastic needle could be used. However, the longer the needle the higher is the resistance to the flow (Hagen-Poisseule Law) and in utilizing a $13.3 \mathrm{~cm}, 14$-gauge needle ${ }^{6}$ we have found pressures in the jetting system above 60 pounds per square inch $(8.7 \mathrm{k} \mathrm{Pa})$ are commonly needed for adequate ventilation. In practice, this means that cylinders of oxygen would be needed in the operating room since pipeline oxygen pressure which is usually 50 pounds per square inch $(7.25 \mathrm{k} \mathrm{Pa})$ will be too little for adequate ventilation. The use of nitrous oxide oxygen blenders is also made impossible and consequently balanced anaesthesia is precluded..$^{7,8}$

The purpose of this paper is to describe the design of a system with which the lungs can be ventilated with nitrous oxide oxygen mixtures while the likelihood of inadvertent puncture of the posterior wall of the trachea or withdrawal into the subcutaneous tissues is minimized. Blood gas analyses on patients undergoing anaesthesia for laryngeal operations during which this technique was used will show its effectiveness under certain specific conditions.

\section{LABORATORY StUdies}

An eight-inch $(20.3 \mathrm{~cm})$ length of corrugated plastic tubing with internal dia-

Edward Carden, M.A., M.B., B.Chir,, F.R.C.P.(C), Associate Professor, Department of Anesthesiology, UCLA School of Medicine, Los Angeles, California, 90024.

Gary Becker, M.D., Assistant Chief, Department of Otorhinolaryngology, VA Wadsworth Hospital Center, Los Angeles, California, 90073, Assistant Professor in Residence, Department of Otorhinolaryngology, UCLA School of Medicine, Los Angeles, California, 90024.

Hassney Hamood, M.D., Resident. Dept. of Otorhinolaryngology, VA Wadsworth Hospital Center, Los Angeles, California, 90073.

Requests for reprints should be sent to: Dr. Edward Carden, Department of Anesthesiology, UCLA School of Medicine, Los Angeles, California, 90024.

Canad. Anaesth. Soc. J., vol. 24, no. 1, January 1977 


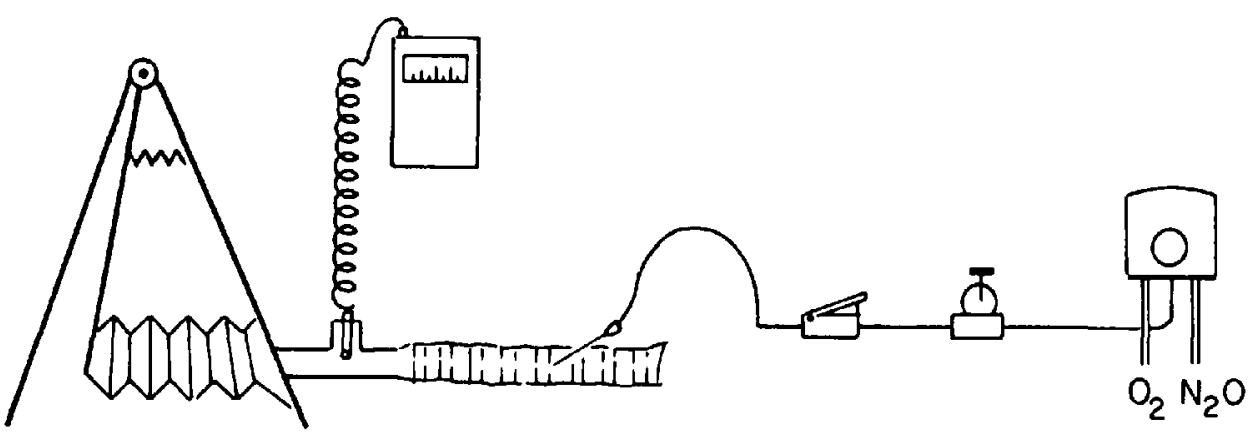

Ficure 1. Schematic representation of the test system used. Shown from left to right are: test lung, oxygen analyzer, simulated trachea, cannula, flow control valve, adjustable pressure reducing valve, and nitrous oxide oxygen blender with appropriate connecting tubes.

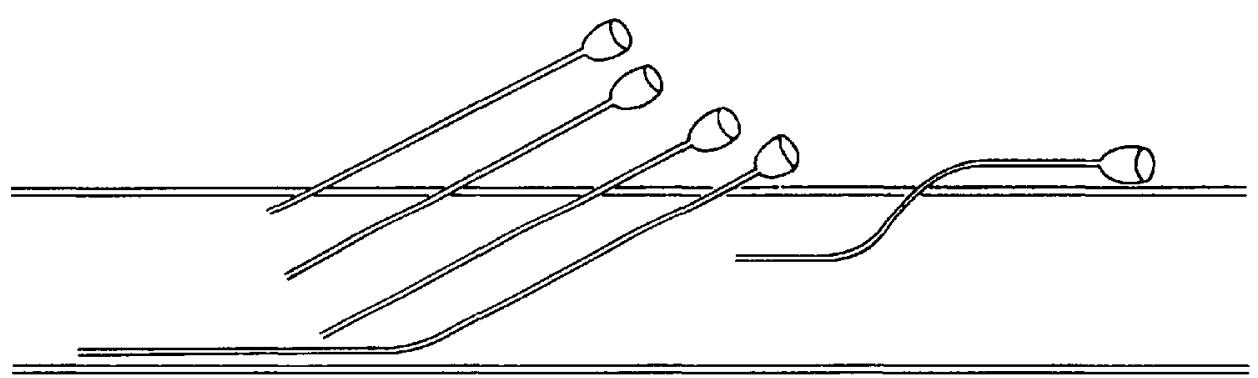

Ficure 2. The position of the cannulae used in the test is shown from left to right: two-inch cannulae one quarter, one half and three quarters across the simulated trachea, then the 133 $\mathrm{mm}$ cannula and lastly the S-shaped cannula.

meter of $2.2 \mathrm{~cm}$ was obtained to simulate an adult trachea in internal diameter but not necessary in length. The larynx of a Laerdal ${ }^{\circ}$ intubation model was attached to its proximal end. A calibrated Manley test lung with a compliance of $50 \mathrm{ml}$ per $\mathrm{cm}$ of water was attached to the distal end. The sensor from an Ohio Model 200 Oxygen Analyzer $\dagger$ was positioned on a $\mathrm{T}$ piece between the test lung and the tubing. A jetting system ${ }^{7}$ was obtained consisting of a high flow nitrous oxide oxygen blender, $\$$ a pressure reducing valve and a flow control valve with the necessary connecting tubing\$ (Figure 1). Intravenous cannulae (Argyle Medicut R\| $5 \mathrm{~cm}$, 14 and 16 gauge) were placed through the wall of the plastic tubing and aimed distally at a thirty degree angle to the longitudinal axis of the tubing (Figure 2). They were inserted at a point approximately two inches from the proximal end of the tube and after insertion the stylets were withdrawn. The maximum pressure was set on the pressure-reducing valve of the jetting system (45 to 47 pounds per square inch; 6.5 to $6.8 \mathrm{kPa}$ ) with the blender set to deliver 100 per cent oxygen. The maximum possible volume which could be delivered per breath to the test

- Laerdal Inc., Buffalo, New York, U.S.A.

tOhio Inc., Madison, Wisconsin, U.S.A.

$₫$ Bird Corporation, Palm Springs, California, U.S.A.

\$Medical Engineering, Racine, Wisconsin, U.S.A.

\|Sherwood Industries, St. Louis, Missouri, U.S.A. 


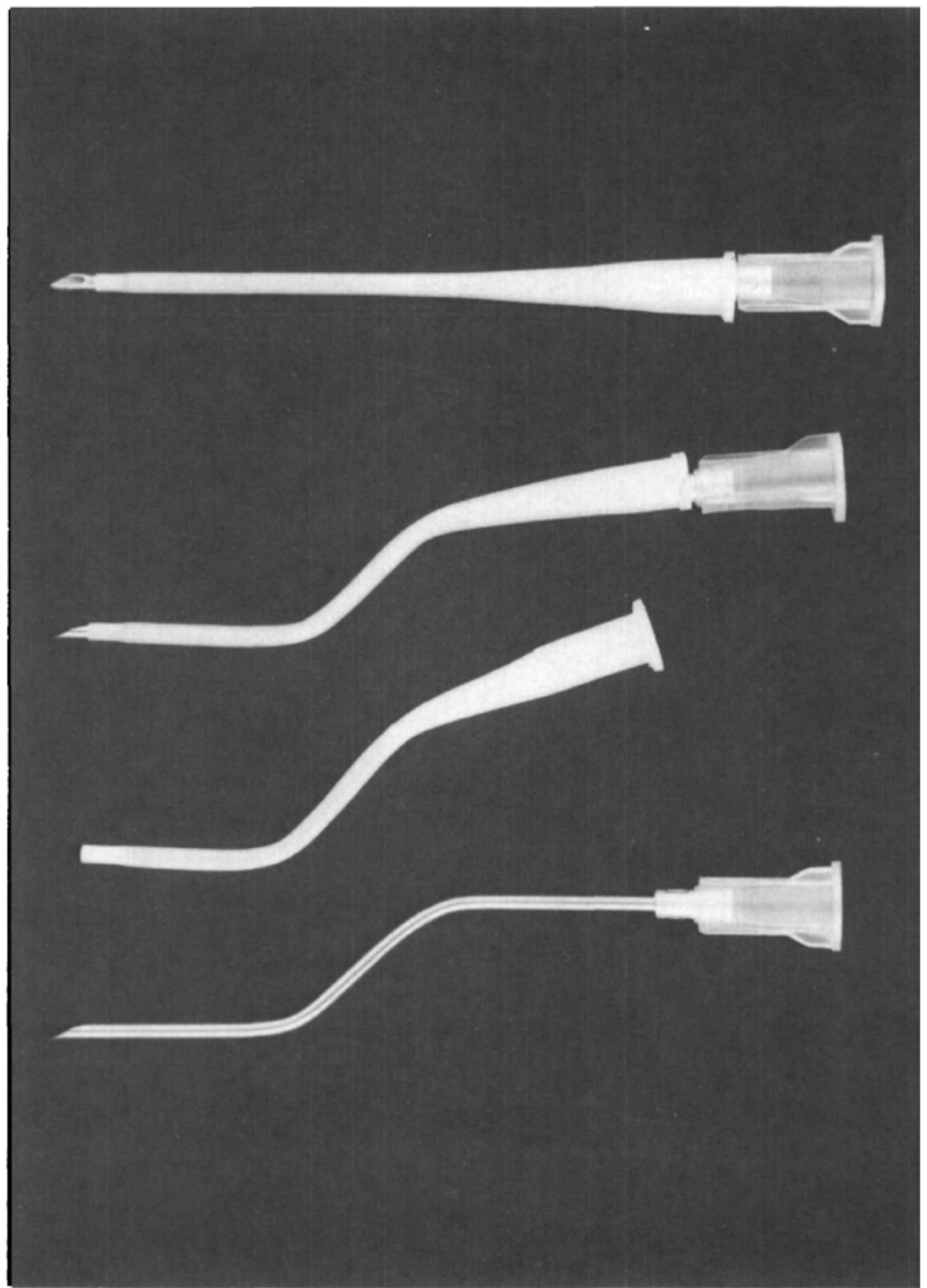

Figure 3. Showing: $A$, the Argyle Medicut $R$ needle; $B$, the needle bent to an $S$ shape; $C$, the stylet removed; D, the stylet.

lung was measured with the tip of the cannula (a) placed approximately one quarter of the way across the simulated trachea, (b) at the midpoint of the trachea, or (c) with the cannula approximately three quarters of the way across the trachea. Then a $13.3 \mathrm{~cm}$ 14-gauge needle (Deseret Angiocath ${ }^{*}$ ) was utilized instead of the $5 \mathrm{~cm}$ needles mentioned earlier. After insertion $1.25 \mathrm{~cm}$ into the trachea, the stylet was

"Deseret Inc., Sandy, Utah, U.S.A. 
TABLE I

Shows the Results of Ventilation of the Test Lung with Different Cannulae

\begin{tabular}{|c|c|c|c|c|c|}
\hline & Needle & & Position & $\begin{array}{l}\text { Tidal } \\
\text { yolume } \\
\text { in cc's }\end{array}$ & $\underset{\text { concentration }}{\mathrm{O}_{2}}$ \\
\hline Gauge & $\begin{array}{l}\text { Length } \\
\text { in inches }\end{array}$ & Shape & & & \\
\hline$\# 16$ & 2 & straight & $\begin{array}{l}1 / 4 \text { in } \\
1 / 2 \text { in } \\
3 / 4 \text { in }\end{array}$ & $\begin{array}{r}60 \\
155 \\
255\end{array}$ & $100 \%$ \\
\hline$\# 14$ & 2 & straight & $\begin{array}{l}1 / 4 \text { in } \\
1 / 2 \text { in } \\
3 / 4 \text { in }\end{array}$ & $\begin{array}{l}160 \\
200 \\
325\end{array}$ & $100 \%$ \\
\hline$\# 14$ & $51 / 4$ & straight & $\begin{array}{l}\text { Lying } 11 \text { to } \\
\text { side wall }\end{array}$ & 410 & $100 \%$ \\
\hline$\# 14$ & 2 & $\mathrm{~S}$ & $\begin{array}{l}\text { in center } \\
\text { of Jumen }\end{array}$ & 660 & $100 \%$ \\
\hline$\# 16$ & 2 & $S$ & $\begin{array}{l}\text { in center } \\
\text { of lumen }\end{array}$ & 435 & $100 \%$ \\
\hline
\end{tabular}

withdrawn and the cannula was advanced until its hub was abutting the wall of the simulated trachea but the tip of the cannula was lying against its far wall parallel to its longitudinal axis. As before, the maximum total volume which could be delivered per breath was measured when gas was jetted at the maximum pressure from the jetting system.

Argyle Medicut $R$ radio-opaque intravenous cannulae 14 and 16 gauge and $5 \mathrm{~cm}$ in length were bent by hand so that they approximated an S (Figure 3). They were then placed in autoclaves at temperatures ranging from $37.8^{\circ} \mathrm{C}$ to $132^{\circ} \mathrm{C}$ for one minute, after which they were removed and allowed to cool. The structure of the cannula and the shape it retained after removal of the stylet were noted. Fourteen- or 16-gauge needles from the batch heated at $98.9^{\circ} \mathrm{C}$ were selected and were inserted through the wall of the simulated trachea in a manner similar to that already described. The stylets were then withdrawn. Since these needles were S-shaped, the terminal one-third was now lying parallel to the longitudinal axis of the simulated trachea, while the middle section of the needle penetrated the wall at an angle approximately 60 degrees to its longitudinal axis and the proximal onethird was lying parallel to the longitudinal axis of the simulated trachea (Figure 2). The tip of the cannula was now positioned approximately in the middle of the air stream. Maximum tidal volumes were measured as before.

In all cases, after the maximum tidal volumes had been obtained, the lung was ventilated with 100 per cent oxygen for one minute at a rate of 15 breaths per minute, or until the reading on the oxygen analyzer had stabilized. At this point the oxygen concentration delivered to the test lung was measured and recorded. For results of the jetting studies and oxygen concentrations delivered see Table I.

\section{Clinical Studies}

Six selected patients who either had large posterior laryngeal lesions or who were suffering from partial respiratory obstruction due to lesions of the larynx 


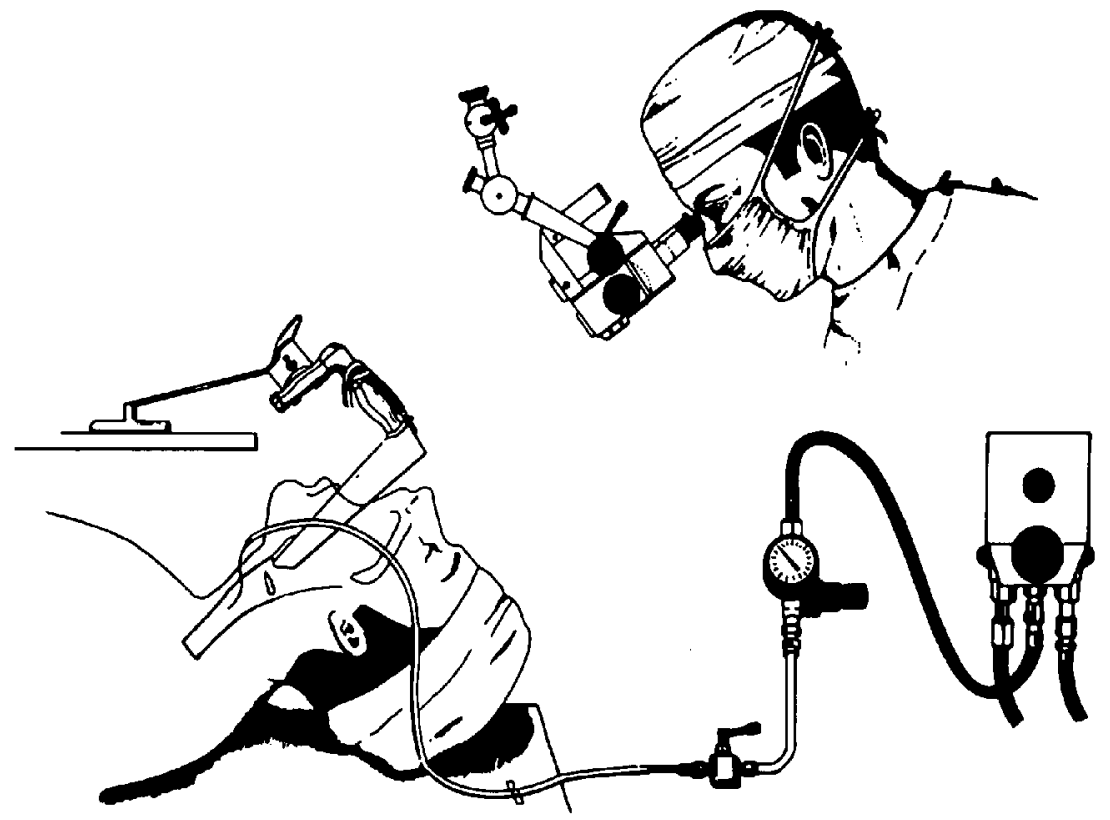

FIGURE 4. An artist's representation of the ventilation system being used for a microlaryngeal operation.

were anaesthetized utilizing a balanced general anaesthetic technique. ${ }^{7}$ For ventilation 14-gauge S-shaped needles prepared in the method described earlier and placed through the cricothyroid membrane were used with the previously mentioned jetting system (Figure 4). Thiopentone was used for induction of anaesthesia and a 0.2 per cent succinylcholine drip for relaxation. An average of $0.2 \mathrm{mg}$ of fentanyl was given intravenously in the course of anaesthesia. Arterial blood samples were taken during operation and analyzed on an IL 113 blood gas analyzer for $\mathrm{P}_{\mathrm{O}_{2}}, \mathrm{P}_{\mathrm{CO}_{2}}$, and $\mathrm{pH}$. The results can be seen in Table II.

\section{RESULTS}

Perusal of Table I makes it clear that with the needle inserted at an angle of 30 degrees through the tracheal wall, the tidal volume in the test lung is higher when the tip of the needle is closest to the distal wall and least when the tip of the needle is closest to the site of puncture. Even using a longer needle with the tip parallel to the longitudinal axis of the simulated trachea, an increased volume was not found. The use of the S-shaped needle places the jet in the centre of the trachea and the direction of the jet is parallel to its side walls. The largest tidal volumes were obtained with this system. In no case was air entrainment detectable on the oxygen analyzer.

Examination of the needles heated at different temperatures in the autoclave revealed that when too low a temperature was used, the cannula would not retain the shape imparted by the stylet after its removal and if higher temperatures were used, the plastic melted and the needle became distorted. The optimal temperature range was $93^{\circ} \mathrm{C}$ to $110^{\circ} \mathrm{C}$. 
TABLE II

Blood Gas Data on Six Patients Undergoing this form of Anesthesia

\begin{tabular}{|c|c|c|c|c|c|c|}
\hline $\begin{array}{l}\text { Patient } \\
\text { no. }\end{array}$ & $\% \mathrm{~N}_{2} \mathrm{O}$ & $\mathrm{PaO}_{2}$ & $\mathrm{PaCO}_{2}$ & $\mathrm{pH}$ & $\begin{array}{l}\text { Age } \\
\text { (Years) }\end{array}$ & Comments \\
\hline 1 & 60 & 170 & 34 & 7.46 & 54 & $\begin{array}{l}\text { Two large laryngeal } \\
\text { polyps. Non-intubatable }\end{array}$ \\
\hline 2 & 60 & 170 & 31.8 & 7.466 & 63 & $\begin{array}{l}\text { Large right posterior } \\
\text { cord lesion }\end{array}$ \\
\hline 3 & 50 & 202 & 31.2 & 7.49 & 70 & $\begin{array}{l}\text { Oedematous right ary- } \\
\text { epiglottic folds. Could } \\
\text { not be intubated }\end{array}$ \\
\hline $\begin{array}{l}4 \\
5\end{array}$ & $\begin{array}{l}65 \\
50\end{array}$ & $\begin{array}{l}140 \\
201\end{array}$ & $\begin{array}{l}30 \\
43\end{array}$ & $\begin{array}{l}7.50 \\
7.33\end{array}$ & $\begin{array}{l}75 \\
74\end{array}$ & $\begin{array}{l}\text { Web across the larynx } \\
\text { Carcinoma of larynx. } \\
\text { Profound airway } \\
\text { obstruction }\end{array}$ \\
\hline 6 & 70 & 119 & 33.5 & 7.445 & 57 & $\begin{array}{l}\text { Post radiation for } \\
\text { carcinoma of larynx. } \\
\text { Very oedematous cords }\end{array}$ \\
\hline
\end{tabular}

The blood gas data shown in Table II show that adequate ventilation and oxygenation is achieved with this system of ventilation.

\section{Discussion}

These results show that the S-shaped cannula provides better ventilation than other needles tested. Therefore, as far as ventilation is concerned it provides an advantage over other types of needle. Even though the long needle had its directional flow parallel to the walls of the simulated trachea, the greater length increased the resistance to flow and therefore the total flow issuing from the needle can be assumed to be significantly less than that from a shorter one. This results in a smaller tidal volume in the test lung. It is interesting to note that Spoere ${ }^{1}$ found 16-gauge cannulae adequate in his hands. However, the reason we began these experiments was that, using 14-gauge and 16-gauge cannulae we were able to get adequate ventilation in our patients.

The second advantage with the S-shaped cannla is that when it has been positioned within the trachea and the stylet has been withdrawn, its shape minimizes the tendency to become partially dislodged with the tip in the subcutaneous tissues.

The third advantage is that by inserting the cannula with the first part of the $S$ through the skin and then lowering the hub somewhat, so that the second part of the $S$ can take the same path as the first, the likelihood of puncture of the posterior wall is virtually eliminated except in a very small child with a much narrower trachea. We have found in practice that the stylet can be easily withdrawn after insertion into the trachea. This ease of withdrawal is due to the fact that the hub is an integral part of the cannula itself. We did investigate many other cannulae but were unable to find one from which the stylet could be removed after it had been bent into an $S$ shape.

The use of the cricothyroid membrane as a puncture site has not been popular for trans-tracheal ventilation. We have chosen it as the puncture site for three reasons. First, the cricothyroid membrane is commonly used when trans-tracheal blocks are being carried out and is, therefore, a familiar landmark to the anaes- 
thetist. Second, it is a much larger space than that between the tracheal rings and there should be less likelihood of burring the tip of the cannula as it is being positioned. The third advantage is that with the cannula in position a tracheostomy can be done and, in fact, this was the case in patient no. 5 because of the magnitude of the upper airway obstruction. The only disadvantage that we have found is that in order to enable the jetting system to be connected to the hub easily it is necessary to have the patient's neck extended at the time of insertion. However, we do also pull the skin cephalad over the area of the cricothyroid membrane before inserting the needle so that hyperextension of the neck will not have a tendency to dislodge it.

The results in the first six patients on whom this technique was used have been very satisfactory. In all cases these patients were specially selected because they either had distinct upper airway obstruction in the region of the larynx or had very large posterior laryngeal lesions which made general anaesthesia by any other method haxardous. In two of them (patients 4 and 5) we inserted the cannula before induction of anaesthesia because of the magnitude of the airway obstruction. Having assured ourselves that we were able to control ventilation and after preoxygenation, the patients were then anaesthestized.

\section{CoNCLUSION}

Studies carried out in the laboratory have shown that an S-shaped cannula for trans-laryngeal jet ventilation provides a distinct advantage over conventional straight ones. Tidal volumes are larger and the cannula is more stable in position. The tendency to perforate the posterior wall of the trachea during introduction is also minimal. Blood gas data obtained from patients being operated upon with this technique of anaesthesia show that it provides very adequate ventilation and can be effectively used with balanced anaesthesia if a nitrous oxide-oxygen blender is incorporated into the jetting system. It can be put in position before induction of anaesthesia to enable preoxygenation and assist ventilation and can be left in place at the end of the operation until the patient is breathing adequately. If necessary, a tracheostomy can be done with the cannula in situ. It is not proposed that this should be the standard mode of anaesthesia or ventilation for patients undergoing operations on the larynx, but in situations where other methods are not adequate and when significant upper airway obstruction is present, this is an excellent alternative.

\section{ACKNOWLEDMENTS}

The authors would like particularly to thank the Bird Corporation of Palm Springs, California, and Medical Engineering of Racine, Wisconsin for supplying the jetting system, Sherwood Industries of St. Louis, Missouri for supplying the cannulae and Sara Fulwiler for secretarial assistance.

\section{RÉSUMÉ}

Les auteurs ont trouvé en laboratoire que l'aiguille interne d'une canule Medicut 
14 ou 16 peut être enlevée et que la canule externe conserve sa nouvelle forme lorsqu'on lui fait passer une minute à l'autoclave à $210^{\circ} \mathrm{F}$ après l'avoir pliée en $\mathrm{S}$. Une canule en $\mathrm{S}$ présente des avantages marqués sur une canule droite, lorsque l'on utilise la technique du jet intermittent de gaz comprimés transtrachéal comme méthode d'anesthésie.

On peut obtenir des volumes courants peu élevés et la canule demeure plus stable dans la lumière de la trachée. De plus, le danger de perforer le mur postérieur de la trachée durant l'introduction de la canule est moindre.

Les gaz artériels obtenus chez des patients anesthésiés avec cette méthode ont démontré qu'il est possible d'obtenir une ventilation adéquate, et quiune anesthésie balancée satisfaisante est possible si l'on incorpore du protoxyde d'azote au système de jet au moyen d'un mélangeur.

La canule transtrachéale peut être mise en position avant l'induction de l'anesthésie permettant la pré-oxygénation du malade et une ventilation assistée, lors de l'induction. Elle peut être laissée en place après la chirurgie jusqu'au retour d'une ventilation adéquate. Si nécessaire, une trachéostomie peut être effectuée avec la canule en place. Les auteurs ne proposent pas cette méthode d'anaesthésie et de ventilation pour les patients subissant une chirurgie laryngée, mais la présentent comme une excellente alternative dans les situations où les autres méthodes ne sont pas satisfaisantes, surtout en présence d'obstruction au niveau des voies respiratoires supérieures.

\section{REFERENCES}

1. SPOEREL, W.E. \& GheENway, R.E. Techniques of ventilation during endolaryngeal surgery under general anaesthetic. Canadian Anaesthetists' Society Journal 20:369-377 (1973).

2. SMITH, R.B. Transtracheal ventilation during anesthesia. Anesthesia \& Analgesia 53: 225-228 (1974).

3. Sмітн, R.B., et al. Percutaneous trans-tracheal ventilation for anaesthesia and resuscitation. Canadian Anaesthetists' Society Journal 5: 604-611 (1975).

4. Grant, P. Personal Communications (1971).

5. Carden, E. \& Calcatera, T.W. Pneumatocoele of the vocal cords. Anesthesia \& Analgesia (in press).

6. JACOBS, H.B. Needle catheter brings oxygen to the trachea. JAMA 222: 1231-1233 (1972).

7. Carden, E. \& Vest, H.R. Further advances in anesthetic techniques for microlaryngeal surgery. Anesthesia and Analgesia 53: 584-587 (1974).

8. Canden, E. \& Schwesinger, W.B. Further advances in bronchoscopic anesthesia. Anesthesiology 39; 551-555 (1973). 